\title{
BAŞKA DILDE GÖÇ: BIUTIFUL FILMINDE GÖç VE GÖÇMENLiK HALLERi
}

Migration in another Language: Immigration and Immigration Situations in

$$
\text { Biutiful Film }
$$

\section{FIrat GÜNDÜZ*}

\section{öz}

Sinema, sosyolojik araştırmaya veri sunan bir alan olarak, son zamanlarda sosyal bilimsel çalışmalara bir çeşit laboratuvar olarak katkı sağlamaktadır. Bunun en temel sebebi, sinemanın toplumsal olayları/olguları yansıtma potansiyeline sahip olması ve bir nevi projektör misyonu üstlenmesinden ileri gelmektedir. Tam da bu sebeple, bu çalışmada Biutiful filmi göç, göçmenlik halleri ve göçmenlerin hayatta kalma stratejileri çerçevesinde ele alınmıştır. Çalışmanın amacı, Avrupa'ya daha iyi yaşam şansı yakalamak için göçmüş birey ve grupların sorunlarını incelemektir. Biutiful filmine bakarken, bu yazı, iki ana yoldan ilerlemeyi tercih etmiştir. ilki, ana karakterin kişisel hikâyesini göçmen-baba alegorisi üzerinden ele almak, ikincisi ise filme konu olan göçmenlerin (Çinli ve Afrikalı -özellikle Sahraaltı ülkeleri-) hareketinin kuramsal boyutlarını inceleyip hayatta kalma stratejileri ve göçmenlik hallerine bakmaktır. Göçmenlerin hayatta kalma stratejilerinde iki önemli kavram ön plana çıkmaktadır: ilki göçmenleri istihdamdaki rolünü imleyen terhane (sweetshop) kavramıyken ikincisi göçmenlerin sosyal dünyada "atık" ve "işe yaramaz" olduğu algısını ifşa eden (Bauman'a referansla) "Iskarta hayatlar" alegorisidir.

Anahtar Sözcükler: göç, göçmenlik, Biutiful, ıskarta hayatlar, neo-klasik göç teorisi.

\section{ABSTRACT}

Cinema, as a field that provides data to sociological research, has recently contributed to social scientific studies as a kind of laboratory. The main reason for this is that cinema has the potential to reflect social events/phenomena and assumes a kind of projector mission. For this reason, in this study, the film Biutiful is handled within the framework of immigration, immigration situations and survival strategies of immigrants. The aim of the study is to examine the problems of individuals and groups who migrated to Europe in order to have a better chance of life. While looking at the movie Biutiful, this article has chosen to proceed in two main ways. The first is to examine the personal story of the main character through the allegory of

\footnotetext{
* Yüksek Lisans Öğrencisi. İzmir Kâtip Çelebi Üniversitesi, Sosyal Bilimler Enstitüsü, Sosyoloji Anabilim Dalı, İzmir/Türkiye. E-mail: firaatgunduz@gmail.com. ORCID ID: 0000-0003-18663315. 
the immigrant-father, and the second is to examine the theoretical dimensions of the movement of immigrants (Chinese and African -especially Sub-Saharan countries-) that are the subject of the film, and look at the survival strategies and immigration situations. Two important concepts come to the fore in the survival strategies of immigrants: The first is the sweetshop concept, which signifies the role of immigrants in employment, the second is the allegory of "wasted life" (referring to Bauman), which reveals the perception that immigrants are "waste" and "useless" in the social world.

Keywords: migration, immigration, Biutiful, wasted life, neoclassical theory of migration.

\section{Giriş}

Sinema, perdedekinin esin kaynağı olarak toplumu ve toplumsal olguları ele almaktadır. Bu çalışmanın gövdesini oluşturan göç mefhumu da sinemanın sıklıkla ele aldığı ve yorumladığı bir mesele olarak karşımıza çıkmaktadır. Göç, en genel anlamı ile bireylerin ve grupların bulundukları kaynak ülkeden çeşitli sebeplerle menşe ülkelere hareket etmesini anlatmaktadır. Bu yazıda Biutiful filminin kuramsal çerçevesini Neo-klasik göç kuramının makro ve mikro yaklaşımları belirlemektedir.

Neo-klasik göç teorisi, bir taraftan göçün yapısal belirleyicilerinin üzerine odaklanan makro yaklaşımı içerirken diğer taraftan da bireyin çeşitli davranışının göz önünde tutulduğu mikro yaklaşımı barındırmaktadır. Neoklasik göç kuramının makro yaklaşımı, uluslararası göçün, emek arz ve talebi arasındaki coğrafi farklılıklardan doğmakta olduğunu söylemektedir. Sermaye-yoğun ülkelerde emek ihtiyacındaki fazlalık, ücretlerin artmasına yol açmakta ve bu nedenle emek-yoğun ülkelerden (ücretler işçi sayısının fazlalığından düşük olduğu için) işçiler, sermaye-yoğun ülkelere göç etmektedirler. Uluslararası göçe, kısaca, ülkeler arasındaki ücret farklııkları neden olmaktadır ve uluslararası göç hareketinin birincil mekanizmalarını işgücü piyasaları oluşturmaktadır (Abadan-Unat, 2002: 6; Massey vd., 1993: 433-434). Bu açıdan bakıldığında filmin konu edindiği göçün yönünün de emek-yoğun ülkelerden sermaye-yoğun ülkelere doğru gerçekleştiğini görmek mümkündür.

Makro yaklaşımın yanında bir de Neo-klasik göç kuramının mikro bakışı mevcuttur. Bu yaklaşım, bireylerin göç ederken karar almasındaki unsurlara mercek tutmaktadır. Massey ve diğerlerinin gösterdiği gibi, bireysel rasyonel aktörler göç kararı alırken fayda-maliyet hesabı yaparlar ve bu hesaptan maddi getiriler beklemektedirler. Bununla beraber insanlar daha üretken 
olacakları, kendilerini geliştirebilecekleri yerleri seçerler, ancak ilk tercih kârı arttırma ve giderleri minimize etme yönündedir (Massey vd., 1993: 434).

\section{Biutiful}

Alejandro González Iñárritu'nun 2010 yapımlı Biutiful filmi, yönetmenin beşinci uzun metrajlı filmidir. Yönetmen, başta Cannes Film Festivali olmak üzere birçok festivalden ödülle dönmüştür. illk filminden bu yana sinemada adından çok söz ettiren ve filmleri ile "auteur" olmayı başaran Meksikalı yönetmenin önde gelen filmleri şu şekildedir: Amores Perros (2000), 21 Grams (2003), Birdman (2014) ve The Revenant (2015).

İspanya'nın Katalonya bölgesinde çekilen filmin ana karakterleri Javier Bardem (Uxbal) ve Maricel Álvarez (Marambra) tarafından canlandırılmıştır. Uxbal başkişisinin kendi ve etrafındakilerle olan ilişkisi, babalık durumu ile göçmenlik halleri çerçevesinde gelişmektedir. Filmde, Çinlilerin ve Senegal başta olmak üzere Sahraaltı Afrika ${ }^{1}$ ülkelerinden göçmüş grupların yaşam mücadelesi konu edilmiştir. Tüm bunların yanında Uxbal'ın ölülerle konuşabilmek gibi bir de metafizik özelliği bulunmaktadır.

Biutiful filmine bakarken, bu yazı, iki ana yoldan ilerlemeyi tercih etmiştir. İlki, ana karakter Uxbal'ın kişisel hikâyesini göçmen-baba alegorisi üzerinden ilerletmek, ikincisi ise filme konu olan göçmenlerin (Çinli ve Afrikalı) hareketinin kuramsal boyutların inceleyip hayatta kalma stratejileri ve göçmenlik hallerini ele almaktır.

\subsection{Kanser ya da Göçmen Bir Baba}

Filmin henüz ilk sahnelerinde Uxbal bir hastanede muayene olmaktadır ve kısa süre içerisinde kanser olduğunu öğrenir. Ana temaya giriş yapmadan yani asıl tetikleyici meseleleri tanımadan (sinemanın diliyle söylemek gerekirse action déclencheurden önce) Uxbal'ın hastalığını gören seyirci onun kaybedecek bir şeyi olmayan, ne de olsa yakın zamanda ölecek (doktor kemoterapi görmesi halinde en fazla birkaç ay yaşayabileceğini söyler) bir "zavallı" olduğunu düşünebilir, ancak kısa süre sonra Uxbal'ın hem iki çocuğuna, hem kendisine sığınan -tabi karşıığında para da aldığını unutmadan-

\footnotetext{
${ }^{1}$ Bu noktada genelde Sahraaltı Afrika ülkeleri özelde ise Senegal'in ele alınmasının sebebi, bölgedeki yoğun yoksulluktan kaynaklanmaktadır. González Ferrer ile Baizán'ın (2010) yaptıkları çalışmaya göre, bu bölgenin ekonomik açıdan yeterli olmayışı ve ispanya başta olmak üzere çeşitli Batı Avrupa ülkesindeki istihdam fırsatlarının mevcudiyeti, göç üzerindeki başat etmendir. Avrupa'da bulunan Senegalli göçmenlerin sayısı ise isspanya, Portekiz, Yunanistan ve Italya'da toplam 41,476 iken (De Haas, 2010: 61) bu sayı sadece İspanya'da 31,507 olarak kayıtlara geçmiştir (De Haas, 2010: 29).
} 
göçmenlere hem de sağlık sorunları olan eski karısına babalık yaptığını görürüz. Bu noktada tartışılmaya değer iki mesele vardır Uxbal için: Kanser ve babalık.

Uxbal'ın kanser oluşu üstü kapalı bir şekilde göçmenliğe gönderme yapmaktadır. Kendisinin de bir süre sonra göçeceğine yapılan bu vurgunun kanser üzerinden gelişmesi, kanserin simgesel olarak kaçınılmaz ölümü çağrıştırmasından kaynaklanmaktadır. Yani yönetmenin mesajı ölüm ile göç arasındaki ilişkiyi vurgulamaktır. Bunu pekiştirmek için Uxbal'ın doğmadan önce göçen babasının hikâyesinin altı çizilir. Babası siyasi olaylardan ötürü daha iyi yaşam şartları için Meksika'ya göçmüştür ve kısa süre içerisinde hayatını kaybetmiştir.

Diğer taraftan Uxbal adına babalık kavramının altını çizmek gerekmektedir. Yönetmen film üzerine olan bir yazısında Biutiful'un bir "babalık" filmi olduğuna dikkat çekmiştir (Iñárritu vd., 2011). Aynı zamanda Iñárritu'nun, filmi kendi babasına adadığını da hatırlatmakta fayda vardır. Uxbal, ölüm ile yüz yüze geldikten sonra çocuklarına ne olacağını düşünür, bu klasik bir baba refleksidir. Kendisi de babasız büyümüş olan ana karakter çocuklarının da o şekilde büyümesini istemez. Ancak Uxbal, sadece çocuklarına değil, kendi himayesi altında çalışan göçmenlere karşı da bir babalık refleksi geliştirmiştir. Sözgelimi, sınır dışı edilen bir Afrikalı göçmenin karısı ve çocuğuna evini açar, onların bir yıllık kiralarını karşılar hatta bunu yaparken kendi öz çocukları için ayırdığı parayı da göçmenin İspanya'da kalan karısına (İge) emanet eder. Aynı şekilde Çinli göçmenlerin kişisel problemleriyle ilgilenir ve onların iş bulmalarında önemli rol oynar. Ancak filmin sonlarına doğru Uxbal'ın ucuz olduğu için aldığı gaz sobaları otuzdan fazla Çinli göçmenin ölümüne neden olur, bu da Uxbal'ın babalığındaki kanserdir.

Uxbal karakteri üzerine konuşulması gereken bir başka konu da filmde yarattığı büyülü dünya olmalıdır. Kuşkusuz sözü edilecek bu büyülü gerçekçilik, Latin Amerikalı yönetmenin, Jorge Luis Borges, Miguel Angel Asturias ve Gabrel Garcia Márquez'den etkilendiğine delalettir. Öyle ki Uxbal'ın, ölülerle konuşabilen ve onların son arzularının yerine getirilmesi için önayak olan, "kutsanmış" kişi olması, izleyici dâhil kimse tarafından yadırganmaz. Uxbal'ın bu yeteneği, yani ölülerle konuşabilmesi ve onların isteklerini dillendirebilmesi, göçmenlerle arasındaki ilişkide bir koşutluk göstermektedir. Tıpkı ölüler gibi, göçmenlerin de istekleri, dertleri ve mücadeleleri Uxbal tarafından dile getirilir. Sözgelimi, Çinli göçmenler ile Barselona polisi arasındaki köprü -rüşvet, güvenlik vs. gibi konularda- Uxbal'dır. 
... ölüler ile yakınları arasındaki konuşmalara aracılık etmesi onun tıpkı göçmenlerle işverenler arasındaki aracılığına benzemektedir. Göçmenleri işverenlere getirerek de para alır, ölülerden dirilere haber getirerek de para alır. Her iki durumda da "aracı"dır (Söylemez, 2015: 126).

Filmin başından sonuna kadar, her uyuduğunda tavanda siyah kelebekler görmektedir Uxbal. Bu kelebekler, Latin Amerika mitlerinde hayatın kısalığını simgelemektedir, renginin siyah olması da kötü şans ve ölüm ile ilişkilidir. Büyülü gerçekçi bu dünyanın sınırları, Uxbal için daralmakta ve ölüm yaklaşmaktadır. Her geçen gün artan kelebek sayısı bir gece sıfıra iner ve Uxbal, yeteneğini kızına devredip hayattan "göçer".

\subsection{Göçmenin Bakışı}

Biutiful filminin bir başka okuması da Barselona'da hayatta kalmaya çalışan göçmenler üzerinden yapılabilir. Bu noktada karşımıza filmin odak noktasına aldığı Afrikalı ve Çinli göçmenler çıkmaktadır. Uluslararası göç kuramlarından Neo-klasik göç kuramı, Afrika kıtasından ya da Uzak Doğu Asya'dan insanların neden Batı Avrupa'ya göçtüklerini anlamlandırmak için kullanılabilecek bir bakış açısı sunmaktadır. Neo-klasik ekonomi kuramından esinlenerek oluşturulan bu göç teorisi, hem göçün yapısal belirleyicilerinin üzerine odaklanan makro yaklaşımı hem de bireyin münferit davranışının göz önünde tutulduğu mikro yaklaşımı içermektedir. Toksöz'e göre makro yaklaşımın göçe bakışı, sermayenin ve emeğin eşitsiz coğrafi dağılımından kaynaklanması, dolayısıyla ücretlerin ve yaşam standardının eşitsizliği ortaya çıkışı çerçevesinde ele alınmaktadır. Sonuç olarak göç, arzın itmesi ve talebin çekmesine bağlı olarak yaratıır (Toksöz, 2006: 16).

Sözü edilen itme-çekme güzellemesi, Everett Lee'nin 1966 yılında yazdığı "A Theory of Migration" makalesine bir göndermedir. Lee, çalışmasında göçün belli başlı parametreleri olduğunu, birtakım "itici" ve "çekici" faktörün menşe yer ile hedeflenen yer arasındaki ilişkileri belirlediğini öne sürmüştür. Göçün kararının alınması aşamasında ortaya çıkan dört faktör, itme-çekme kuramı olarak da bilinen yaklaşımı oluşturmaktadır (Lee, 1966: 49-50). ${ }^{2}$ Ancak Lee'nin kuramı, Biutiful filmindeki göçü açıklamakta eksik kalmaktadır. Uluslararası göç üzerinden belirleyici olan temel dinamiği işgücü piyasaları olarak gören Neo-klasik göç kuramı, ülkeler arasında var olan ücret ve istihdam şartlarındaki farklara ve göçün maliyetine odaklan-

\footnotetext{
${ }^{2}$ Bu dört faktörü Lee şu şekilde ele almaktadır: 1. Menşe yer ile ilişkili faktörler, 2. Hedef yer ile ilişkili faktörler, 3. Araya giren engeller ve 4. Bireysel faktörler (Lee, 1966).
} 
maktadır; kuram genel olarak hareketi geliri maksimize etmek amaçlı bireysel bir karar olarak tasavvur etmektedir (Massey vd., 1993: 432). Bu sayede Biutiful filminde karşımıza çıkan göç çeşidi, Neo-klasik göç kuramı ile daha anlaşılır olacaktır.

Neo-klasik göç kuramının makro yaklaşımı, uluslararası göçün, tıpkı iç göç gibi, emek arz ve talebi arasındaki coğrafi farklılıklardan doğduğunu söylemektedir. Sermaye-yoğun ülkelerde emek ihtiyacındaki fazlalık, ücretlerin artmasına yol açmaktadır. Bu nedenle emek-yoğun ülkelerden işçiler, ücretler işçi sayısının fazlalığından düşük olduğu için sermaye-yoğun ülkelere göç ederler. Uluslararası göçe, kısaca ülkeler arasındaki ücret farklılıkları neden olmaktadır ve uluslararası göç hareketinin birincil mekanizmalarını işgücü piyasaları oluşturmaktadır (Abadan-Unat, 2002: 6; Massey vd., 1993: 433-434). Bu açıdan bakıldığında filmin konu edindiği göçün yönünün de emek-yoğun ülkelerden sermaye-yoğun ülkelere doğru gerçekleştiğini görmek mümkündür. González Ferrer ile Baizán'ın (2010) yaptığı çalışma Senegal'in istihdam açısından zayıflığını, dolayısıyla göç verdiğini göstermektedir. Keza filmde de göçmenler, ispanya'da bulunmalarının en elle tutulur sebebi olarak istihdamı göstermektedirler.

Sınır dışı edilmek istenen Afrikalı göçmen Ekweme'nin karısı İge ile konuşmasını hatırlayalım: Kendisinin tekrar ülkeye girmeyi deneyeceğini; işsizlik, kötü yaşam koşulları ve eğitimsizlik hasebiyle Senegal'de hayatta kalamayacaklarını söyleyen Ekweme, artıları eksileri bir tarafa bırakıp canı pahasına bu yolu tekrar geçeceğini belirtir. Diğer taraftan içerisinde çocukların hatta bebeklerin de bulunduğu otuz kadar Çinli göçmen, çalıştıkları tekstil atölyesinin bodrum katında kilitli olarak kalmaktadır. Sabahları erkenden çorba ve ekmekle kahvaltılarını yapıp bir başka Çinli atölye sahibi için işbaşı yapmaktadırlar. Patronları tarafından hakları korunmayan Çinli göçmenler için, Uxbal ve patron arasında geçen diyalog, konunun anlaşılırlığı açısından elzemdir. Çinli patron, kendisine göçmenlerin emeklerinden söz eden Uxbal'a "Çin'de beş sente çalışacağına burada bir dolara çalışsın" der. Oysa Barselona'da bir doların anlamı, Çin'deki beş sentten daha değerli değildir. Kaldı ki aldıkları ücret nitelik bakımından eşit olsa bile işe ikincil önemde olan konfor, eğitim, kişisel gelişim ya da sağlıklı bir gelecek gibi göçü doğrudan etkileyen başka etmenler de eklenmektedir. Şimdi söz konusu etmenleri ele alan yaklaşımlara bakmakta fayda vardır.

Makro yaklaşımın yanında bir de Neo-klasik göç kuramının mikro bakışı mevcuttur. Bu yaklaşım, bireylerin göç ederken karar almasındaki unsurlara mercek tutmaktadır. Massey ve diğerlerinin gösterdiği gibi, bireysel rasyonel 
aktörler göç kararı alırken fayda-maliyet hesabı yaparlar ve bu hesaptan maddi getiriler beklemektedirler. Bununla beraber insanlar daha üretken olacakları, kendilerini geliştirebilecekleri yerleri seçerler, ancak ilk tercih kârı arttırma ve giderleri minimize etme yönündedir (Massey vd., 1993: 434). "Özellikle illegal yollardan göçü göze alan kişiler, sınır dışı edilme ihtimalini de bu hesaplara dâhil etmektedirler" (Abadan-Unat, 200: 7). Hülasa, mikro yaklaşıma göre, uluslararası göç hareketi hem kazançtan hem de beklenen kazancı belirleyen istihdam oranlarındaki uluslararası farklardan kaynaklanmaktadır (Massey vd., 1993: 435). Bu noktada göçü ortaya çıkaran şey, daha yüksek ücret sunan yerlere giderek yaşam standardını yükseltmek isteyen rasyonel bireylerin aldıkları kararlardır. Göçün fayda-maliyet analizinden sonra, tüm gerçeklerin bilincinde olarak göç kararı, bireyce gönüllü olarak alınır. Böylece göçmenler beklenen faydanın en yüksek olduğu yerleri hedef olarak seçmeye karar verirler (Toksöz, 2006: 17).

Mikro yaklaşımın tezahürlerini, Afrikalı göçmenin yakalanıp sınır dışı edildiğinde söylediklerinde bulmak mümkündür ve onun söyledikleri, göçmenin neden hala kalmaya devam etmek istediğini anlamamızı sağlamaktadır: "Biz burada da kötü durumdayız, Senegal'de de kötü olacağız. Ama burada kalırsak Samuel (çocukları) ispanyol olacak, daha iyi eğitimi daha iyi hayatı olacak”. Yani göçmenler, ekonomik olanakları sağlamanın yanında, tıpkı Neo-klasik kuramın mikro yaklaşımının belirttiği gibi, ailelerini, konforlarını ve geleceklerini de fayda-maliyet hesabı üzerinden maksimum fayda ile yakalamaya çalışılar.

Bu noktadan sonra ülkelerinden kalkıp Avrupa'ya, daha iyi bir yaşam şansı yakalamak için gelen göçmenlerin hayatta kalma stratejilerine bakmakta gerekir. Afrikalı göçmenler, bir evde büyük kalabalıklar halinde yaşamaktadırlar. Bunun sebepleri giderlerin bölünmesi ve daha önemlisi göçmenlerin kendi aralarında bir dayanışma ağı kurmak istemesinden ileri gelmektedir. Göçmenlerin hayatta kalmak için yaptıkları işler, daima sınırları zorlamakta ve gelirin gideri karşılamadığı gözlenmektedir. Zaten devamlı kayıt-dışı çalışmaktadırlar. Çinlilere bir iş ayarlayan Uxbal'a işveren beklediğinden az para teklif edince, Uxbal işvereni sendikalı işçilerle çalışmak zorunda bırakmakla tehdit eder: "Sendikalı işçi çalıştır sen de o zaman, başka seçeneğin kalmazsa beni ara."

Bu noktada İspanya'da daha iyi bir yaşam isteyen göçmenlerin çalışma atölyeleri üzerinde durmak gerekir. İçlerinde çocukların da bulunduğu çalışma ortamları iş güvenliği ve hijyen şartları açısından yasal gerekliliklerden çok uzaktadır ve genellikle bu tarz atölyelerin havasız ve bakımsız yerler 
olması bu atölyelere Türkçeye "terhane" olarak çevrilen "sweatshop" isminin verilmesine yol açmıştır (Zwolinski'den akt. Yıldız ve Yıldız, 2017: 100). Ingilizce literatürde "sweathop" olarak bilinen terhanelerin tanımı çeşitlilik göstermektedir. Arnold ve Hartman bir sweathop'u şöyle tanımlar:

[Sweatshoplar] işçilerin tipik olarak aşağıdaki koşullardan ikisine veya daha fazlasına maruz kaldığı herhangi bir işyeri olarak tanımlamaktadır: Haftalık 48 saat çalışma geliri ki bu ülkenin genel yoksulluk oranından daha azdır; sistematik olarak zorla fazla mesai; ihmal veya çalışan refahını kasıtlı olarak dikkate almama nedeniyle sistematik sağlık ve güvenlik riskleri; baskı; işçileri riske atan sistematik aldatma ve kazançların az ödenmesi. (akt. Zwolinski, 2007: 715).

Koşut olarak ABD Genel Muhasebe Ofisi de terhaneyi ücret veya çocuk işçiliği ile güvenlik veya sağlık yasalarını düzenli olarak ihlal eden bir işletme olarak tanımlamaktadır (Zwolinski, 2007: 715). Bazı kaynaklara göre 18. yüzyıl sonlarında ilk kez ingiltere'de, kimilerine göre ise 19. yüzyılda ABD'de ortaya çıkmıştır, aynı zamanda terhanelerin varlığı, bazılarına göre, Avrupa'dan daha iyi yaşam şansına sahip olmak için Amerika kıtasına göç eden milyonlarca göçmenin çalıştığı tekstil endüstrisine dayanmaktadır (Yıldız ve Yıldız, 2017: 100). Diğer bir taraftan;

kayıt-dışı istihdamın bir uzantısı olarak ortaya çıkan terhaneler, sanayi devriminin hemen sonrasında ortaya çıkmış ve ilk olarak kadın ve çocuk işçilerin çalıştığı, iş güvenliği ve hijyen şartlarından yoksun tekstil atölyeleri olarak ortaya çıkmış fakat zaman içinde işsizliğin artması, uluslararası göçlerin yaşanması ve düşük gelir sebebiyle giderek yaygınlaşmıştır (Yıldız ve Yıldız, 2017: 105).

Bu açıdan bakıldığında Çinli ve Afrikalı göçmenlerin istihdamını sağlayan atölyeler "terhane" olarak tanımlanabilir.

Çinli göçmenler tekstil atölyesinde çanta yaparken bu çantaları Uxbal aracılığı ile Afrikalı göçmenler satmaktadırlar. Uxbal, Afrikalı göçmenleri sık sık göz önünde durmamaları ve "yeraltı" pazarlarında iş yapmaları konusunda uyarmaktadır. Oysa her iki grup da geliri yetmediği için, hâlihazırdaki illegal işlerine illegal daha başka işler eklemekte ya da iş dışında gününü sadece uyumakla geçirmektedirler. ilk tanıma uyanlar, Biutiful filmi özelinde Afrikalı göçmenlerken ikincisini Çinli göçmenler oluşturmaktadır.

Zwolinski'ye göre (2017: 695) terhanede çalışmak isteyen çoğu işçi, seçimlerini kısıtlı seçenekler arasında yapmaktadır ve bu seçeneğin ortadan 
kalkması ihtimali, orada kayıt dışı istihdamdan beslenen insanlara ciddi zararlar verme potansiyeline sahiptir. Afrikalı göçmenlerin uyuşturucu satarak gelirlerini arttırma arzusu, polis tarafından engellendiğinde ve Afrikalı satıcılar sınır dışı edildiğinde, bunu terhanelerin bir seçenek olarak ortadan kalkmasının sonucu olarak okumak mümkündür.

Sınır dışı edilme ile yüz yüze kalan Afrikalıları -onlardan aldığı parayı kullanıp - rüşvetlerle kurtarmaya çalışan Uxbal, polisin şu sözleri ile karşılaşır: "Aç birine güvenmek tehlikelidir, çocukları açsa daha da tehlikeli”. Burada otorite tarafından göçmenin müşkül olduğu de facto olarak kabul edilir ancak aynı polis şu çıkarımı yaparak yine kendini, yani ülkenin yerli, milli ve vatanperver çoğunluğunu savunur3: "Biz pirince talim ederken, en iyi jambonlarla beslenen bir sürü kaçak pislik var". Konuşma sonrasında Afrikalılar sınır dışı edilir ve arkalarında ise dil bilmeyen, işi olmayan, parasız ve çocuklu aileleri kalır. Bunun filmdeki örneği ise İge'dir. Kocasının aksine İge, İspanya'ya ait olmadıklarını, Senegal'e dönmek istediğini ısrarla dile getirmektedir. Çocuğunun bir Senegalli olduğunu ve asla ispanyol olamayacağını içselleştirmiştir. Keza kocası sınır dışı edildikten sonra yeterli parayı bulup Senegal'e dönmenin hayalini kurmaktadır.

\subsection{Iskarta Hayatlar}

Afrikalı göçmenin, sınır dışı edilme sahnesi ve bu olayın hemen arifesinde görünen konuşma, göçmenin yabancılığı ve aidiyeti üzerine başka bir konu açmaktadır. Ekweme ve Ige, ailelerinin geleceğini konuşurlar ve Ekweme, en azından çocuklarının daha iyi bir yaşam şansına erişmesi gerektiğini söyler. Simmel'in yabancısı gibi, göçmen de bugün gelen ve yarın da kalan olarak çıkar karşımıza. "Yabancı" der Simmel, “... terimin bildik anlamıyla burada sayılmaz, bugün gelip yarın giden gezgin gibi değil, bugün gelip yarın kalan adam gibidir" (Simmel, 2009: 149). Yabancı, gelip gitme özgürlüğünden mahrum kalmıştır ancak Ekweme'ye olduğu gibi, gönderilen/gönderilmek istenen olarak çıkar karşımıza. Yabancının aidiyeti, yerli olan ile örtüşmemektedir, bu yüzden olacak ki İge, çocuklarının da kendilerinin de buraya ait olmadığını sık sık tekrarlar. Göçmenin sınırları, Simmel'in yabancıya atfettiği şekilde, mekânsal sınırlara benzeyen bir grup içinde sabitlenmiştir (Simmel, 2009: 149) ve hareket alanı kendi sınırları çerçevesinde çizilmiştir. Robert E. Park'ın Simmel'in yabancısını ele alırken

\footnotetext{
${ }^{3}$ Bu tartışmanın biraz daha farklısı, Bauman'ın Kapımızdaki Yabancılar isimli çalışmasında ele alınmıştır. Tam da aynı refleksler ile hareket eden Macar devlet başkanı, göçmenler için "bütün teröristler göçmendir” (Bauman, 2018b: 31) çıkarımı yapabilmektedir.
} 
kullandığı biçimiyle, yabancı yarın da kalandır ancak yerleşik değildir, yabancı (bu yazıda ele alınan biçimi ile göçmen) yerel olanın kendi özelliklerine ve geleneklerine bağlı değildir (Park, 2019: 58). Park'ın nitelediği “marjinal insan" gibidir göçmen; melezdir, hem kendi tarihselliği hem de bulunduğu yerin gelenekleri arasında var olmaya çalışır. Kuvvetle muhtemel bu tanımlamalarda Ekweme marjinal insanı temsil ederken, İge Simmel'in yabancısı gibi kalacaktır.

Bauman'ın yabancı anlayışı ise göçmene bakışın anahtarlarını sunmaktadır. "Nitekim Bauman, günümüzde mültecileri, devletsizlikleri ve kalacak yeri olmamaları nedeniyle 'mutlak yabancı' olarak nitelendirir" (Bauman'dan akt. Başer, 2011: 113-114). Yabancı, her şeyden önce yerli için müphemdir. Nasıl müphemlik modernliğe karşı bir tehlike durumu arz ediyorsa, yabancı da yerli için aynı tehlikeyi akla getirmektedir. Bauman bu noktada yabancının yaptığını şu şekilde tanımlar:

Karar verilemezlerin [yabancıların] hepsi ne-o/ne-de-şu'dur. Yani bunlar, ya-şu/ya-da-bu'nun aleyhinedir. Eksik belirlenimleri bunların gücüdür. Çünkü bunlar hiçbir şeydirler ve her şey olabilirler. Karşıtlığın düzenleyici gücünü, dolayısıyla da karşıtlık anlatıcılarının düzenleyici güçlerini yok ederler. Karşıtlıklar bilgiyi ve eylemi mümkün kılar; karar verilemezler ise bunları felç eder. Karar verilemezler, karşıtıkların en yaşamsalının bile yapaylığını, narinliğini ve sahteliğini acımadan ifşa eder. Dışarıyı içeriye getirir ve düzenin rahatını kaosun kuşkusu ile zehirler (Bauman, 2003: 78).

Modern çağın, en başından itibaren büyük göçlerin çağı olduğunu düşünen Bauman (2018a: 51), modernitenin düzen ve hesaplanabilirlik düsturunu, bilinmeyenin, müphem olanın bilinebilir, hesaplanabilir hatta düzene sokulabilir hale getirmek için çeşitli yöntemler izlediğinin altını çizmektedir. Ancak bazıları, bilinmezliği, kullanılamazlığı ve lüzumsuzluğu ile atık durumunda kalırlar. İşte Bauman bunları "Iskarta hayatlar" olarak tanımlar.

Filmde Çinli göçmenlerin akıbeti, Afrikalılara nazaran daha trajik ve daha vurucu işlenmiştir. Atölyenin bodrum katında yaşayan Çinliler, geceleri soğuk olduğu için hastalanmakta ve verimi düşürmektedirler. Bunun üzerine işveren, Uxbal'a soba alması için bir miktar para verir. Ancak Uxbal, paraya intiyacı olduğu için ucuz ve kalitesiz gaz sobaları alıp kalan parayı da kendi için ayırır. Bunun üzerine birkaç gün sonra tüm çalışanlar, gaz sızıntısı nedeniyle hayatını kaybeder. Hatta bir kişi tam olarak ölmemesine rağmen bod- 
rum kattan çıkartılmaz, çünkü ona ne yapılacağı bilinmez ve ölmesi beklenir. Bir nevi ıskartaya çıkarıır.

Iskarta (atık) hayatlar Bauman'ın geliştirmiş olduğu bir alegoridir. Iskartaya çıkmış insanlar; standartlara uymayanları, kullanım-dışıı̆ını ve hatta lüzumsuzluğu içermektedir. Iskarta ilan edilmek, gözden çıkarılabilir olduğu için gözden çıkarımayı ifade eder. Bauman nazarında ıskarta ilan edilmek "tıpkı boş ve geri iadesiz bir plastik şişe ya da kullanılmış bir şırınga, alıcısı olmayan sevimsiz bir eşya, kalite uzmanlarının üretim hattından çıkarıp attıkları, standartlara uymayan bozuk bir ürünü gibi” (Bauman, 2018a: 24) tasvir edilmektedir.

Nihayetinde otuza yakın Çinli göçmen, bodrum katta hayatını kaybeder, diğer bir deyişle ıskartaya çıkarlar. Bauman, mültecilerin, sığınmacıların belgesi olmayan kaçak göçmenlerin (bunu kitabında Fransızca "belgesiz" anlamına gelen sans paper kavramı ile kullanır) küreselleşmenin atıkları olduğunu söyler (Bauman, 2018a: 74). Meseleyi daha da trajik hale getiren ise göçmenlerin ölümünden sonra müsebbiplerin takındıkları tavırdır. Uxbal kendini bunun bir kaza olduğuna inandırır, vicdanını rahatlatmaya çalışır, zaten kısa süre içerisinde kendisi de ölecektir, biliyordur. Çinli patronlar ise kendilerine ne olacağını daha fazla dert ederler. Sonunda hapse girmemek için bir yol bulurlar: Cesetleri denize atmak. Bu çözüm iki açıdan önemlidir. ilki, cesetlerin batacağı düşüncesidir. Cesetler denizde kaybolur ve kayıtları olmadığı için yoklukları da anlaşılmaz. İkincisi ise cesetlerin batmaması durumunda ortaya çıkar (keza öyle de olur). Cesetler batmayınca da zımnen, Barselona'nın kıyılarına varmaya çalışan ancak denizde boğulan bir grup sığınmacı süsü, suçluları suçlardan arındıracaktır. Avrupa'ya ulaşmak için denizlerde hayatını kaybeden bugünün göçmenlerini göz önüne aldığımızda, işin trajik boyutunun öngörüldüğü anlaşılmaktadır. Hülasa, Bauman'ın da belirttiği gibi, ıskarta hayatlar; yani adapte olamayan, asimilasyona direnen ve işsizlik doğuran atıklar (Bauman, 2018a: 94), toplumun sağlığı göz önünde bulundurularak (Bauman, 2018a: 102) rahatlıkla gözden çıkarılırlar.

\section{Sonuç}

Göç, birçok sosyal bilimcinin nazarında insanlık tarihi kadar eski bir olgudur. Ancak içinde bulunduğumuz çağda göçün anlamı, en kestirme yolla söylemek gerekirse, insanlık trajedileri ile ilişkilendirilmektedir. Sinema da halihazırda toplumsal olayları ele alıp bir projeksiyon işlevi görmektedir. Onun bu misyonu, sosyal bilimsel araştırma için bir veri mekanizması olarak 
işlev görmektedir. Avrupa'ya Ortadoğu ve Afrika ülkelerinden kitleler halinde göçün başladığı 2010 yılında, inarittu'nun yaptığı Biutiful filmi Barselona'da hayatta kalmaya çalışan göçmenlerin içerisinde bulundukları durumu bir insan kaçakçısının gözünden anlatmaktadır. Göçmenler, hayatta kalmak için terhane adı verilen istihdam alanlarında ucuz-emek gücünü kullanarak kendinden sonra gelen nesillere daha iyi bir yaşam şansı sunmayı amaç edinmişlerdir. Bu noktada karşılaştıkları zorluklar ve gördükleri muameleler, göçmenin atık olduğunu, ıskartaya çıktığını göstermektedir. Filmin söyledikleri, günümüzün göç sorununa bakmak için önemli ipuçları vermektedir.

Biutiful filmi, ana karakterin çocuklarının yanı sıra aracılığını yaptığı göçmenlere de babalık yaptığı ve onun bu işi sorumluluğa dönüştürdüğü fikri ile başlamaktadır. Ancak filmin alt metinlerinde, özelde Senegalli ve Çinli göçmenlerin yaşadıkları problemleri göstermektedir. Göçmenler, daha iyi bir yaşam şansı yakalamak için geldikleri ispanya'da hayatta kalmak için enformel işler yürütmektedir. Bu noktada göçmenlerin maruz kaldıkları muamele yerli halkın onlara bakışı ve yükselen göç sürecine devletin müdahalesi en trajik boyutları ile aktarılmıştır. Bu yazı, göç sürecini Neo-klasik göç teorisi etrafında ele almıştır. Birinci bölümde ana karakterin göçmenlerle ilişkisi babalık alegorisi üzerinden ele almıştır. Akabinde göçmenlerin bakış açısının verilmesi amacıyla onların hayatta kalma stratejilerine değinilmiştir. Son olarak göçmenlere bakışın anahtarları Bauman'ın "ıskarta hayatlar" güzellemesi çerçevesinde işlenmiştir.

\section{Kaynakça}

Abadan-Unat, Nermin (2002). Bitmeyen Göç: Konuk Iş̧̧ilikten Ulus-Ötesi Yurttaşlığa. İstanbul: İstanbul Bilgi Üniversitesi Yayınları.

Başer, Doğa (2011). Zygmunt Bauman'da Müphemlik ve Toplumsal Yaşam.

Yüksek Lisans Tezi. Afyon: Afyon Kocatepe Üniversitesi Sosyal Bilimler Enstitüsü.

Bauman, Zygmunt (2003). Modernlik ve Müphemlik. Çev. İsmail Türkmen. İstanbul: Ayrıntı Yayınları.

Bauman, Zygmunt (2018a). Iskarta Hayatlar. Modernite ve Safraları. Çev. Osman Yener. İstanbul: Can Yayınları.

Bauman, Zygmunt (2018b). Kapımızdaki Yabancılar. Çev. Emre Barca. İstanbul: Ayrıntı Yayınları. 
De Haas, Hein (2008). Irregular Migration from West Africa to the Maghreb and the European Union: An Overview of Recent Trends. Geneva: IOM.

González Ferrer, Amparo and Baizán, Pau (2010). "Destination Choices Among Senegalese Migrants in Europe. The Role of Labor Market and Immigration Policies". European Population Conference. Vienna.

Iñárritu, A. Gonzáles et al. (2011). Biutiful. Prokino.

Lee, Everett S. (1966). A Theory of Migration. Demography, 3(1): 47-57.

Massey, Douglas S. et al. (1993). "Theories of International Migration: A Review and Appraisal". Population and Development Review, 19(3): 431466.

Park, Robert E. (2019). "Insan Göçü ve Marjinal insan”. Yabancl: Bir ilişki Biçimi Olarak Ötekilik. Der. Levent Ünsaldı. Ankara: Heretik Yayınları.

Simmell, Georg (2009). Bireysellik ve Kültür. Çev. Tuncay Birkan. İstanbul: Metis Yayınları.

Söylemez, Yavuz Selim (2015). "Sinemada Göçmen Sorunu ve Iñárritu'nun Göçü: Biutiful”. Marmara iletişim Dergisi, 24: 123-130.

Toksöz, Gülay (2006). Uluslararası Emek Göçü. İstanbul: İstanbul Bilgi Üniversitesi Yayınları.

Yıldız, Zafer ve Yıldız, Savaş (2017). "Kayıt Dışı Ekonomi Bağlamında, Dünya ve Türkiye'de Kayıt Dışı İstihdam, Terhaneler ve Çocuk İ̧̧̧̧iler”. Sosyal ve Ekonomik Araştırmalar Dergisi, 19(32): 96-106.

Zwolinski, Matt (2007). "Sweatshops, Choice, and Exploitation". Business Ethics Quarterly, 17: 689-727.

\footnotetext{
"COPE-Dergi Editörleri İçin Davranış Kuralları ve En İyi Uygulama ilkeleri” çerçevesinde aşağıdaki beyanlara yer verilmiştir:
}

Etik Kurul Belgesi: Bu çalışma için etik kurul belgesi gerekmemektedir.

Çıkar Çatışması Beyanı: Bu makalenin araştırması, yazarlığı veya yayınlanmasıyla ilgili olarak yazarın potansiyel bir çıkar çatışması yoktur.

The following statements are made in the framework of "COPE-Code of Conduct and Best Practices Guidelines for Journal Editors":

Ethics Committee Approval: Ethics committee approval is not required for this study.

Declaration of Conflicting Interests: The author has no potential conflict of interest regarding research, authorship or publication of this article. 